\title{
Section 377: A legal \& political outlook of India
}

\section{Sección 377: Una perspectiva legal y política de la India}

\section{Abir Mondal}

Ramakrishna Mission Brahmananda College of Education - India

Kolkata, India

rkmbcrahara@gmail.com

\begin{abstract}
In India, homosexual intercourse is legal now, but the legalization battle was not so easy; many obstacles were there. In 1860, Section 377 was introduced in the constitution by the British Government which declared homosexual intercourse illegal. As a result, the law considers the individuals of the LGBT community criminal. So, for gay rights, many NGOs and gay social activists have protested 377 repeatedly. They through the legal path achieved success by legalizing adult homosexuality on September 6, 2018. This theoretical case study focuses on the elaborative discussion on the pathetic social status of homosexuals from 1991 to 2018 due to article 377 which makes it clear why the read down of article 377 is needed for the sake of the Right to Privacy given by the Constitution of India.
\end{abstract}

Keywords: Homosexuality; LGBT; Third Gender; India

\section{RESUMEN}

En la India, las relaciones homosexuales son ahora legales, pero la batalla por la legalización no fue tan fácil; había muchos obstáculos. En 1860, el Gobierno británico introdujo en la Constitución la Sección 377, que declaraba ilegales las relaciones homosexuales. En consecuencia, la ley considera criminales a los individuos de la comunidad LGBT. Por ello, en favor de los derechos de los homosexuales, muchas ONG y activistas sociales homosexuales han protestado contra la 377 en repetidas ocasiones. Ellos a través de la vía legal lograron el éxito al legalizar la homosexualidad adulta el 6 de septiembre de 2018. Este estudio de caso teórico se centra en la discusión elaborativa sobre el patético estatus social de los homosexuales desde 1991 hasta 2018 debido al artículo 377 que deja claro por qué la lectura del artículo 377 es necesaria por el bien del Derecho a la Privacidad dado por la Constitución de la India.

Palabras clave: Homosexualidad; LGBT; tercer género; India 


\section{INTRODUCTION}

India is a country of diversity in culture, heritage, language, race, and religion with the majority of Hindus (79.8\%) and some proportion of Muslims (14.2\%), Christians (2.3\%), Sikhs (1.72\%), Buddhists (0.7\%) and Jains (0.37\%) as per the census of 2011. But all these conclude in one place, i.e., religious prejudices, and this makes homosexuality illegal for more than 100 years. Some flag bearer, Hindutva, said that in Hindu mythology and Indian culture homosexuality is prohibited. It is a western concept. But some historians like Saleem Kidwai, Shakuntala Devi, Jeffrey S. Siker, Ruth Vanita, and Devdutt Pattanaik showed by homosexual sculpture in Khajuraho temple and Kama Sutra (ancient Indian Sanskrit text on sexuality, eroticism), written by Vatsyayan, that same-sex is there in Indian culture from the ancient time. Kidwai wrote, "During the early medieval period, there are a few scattered references to same-sex love; while in the late medieval period, a huge body of literature on same-sex love develops" (Vanita \& Kidwai, 2001, p.107).

Secondly, the constitutional perspective where Section 377 criminalizes homosexual intercourse which directly violates the Constitution of India because in Part III (Fundamental Rights) of the Constitution some articles clearly emphasize equality in every aspect. Like,

Article 14: Equality before law and equal protection of law.

Article 15: Prohibition of discrimination on grounds of religion, race, caste, sex or place of birth.

Article 21: Protection of life and personal liberty. (Laxmikanth, 2020, p. 73)

Here in Art. 15, the word 'Sex' arises a question. In the Constitution, there is no provision of 'Sex'. In today's context, 'Sex' also includes Third Gender. So, by implementing Section 377, the Constitution makes discrimination against these people. In addition, as per Art. 21, there should be the protection of life and personal liberty of all citizens which contradicts the Constitutional Art. 377. This makes the uncertainty of the Constitution, which is not desirable at all.

Lastly, the sociological aspect like we directly question the freedom of choice. Society has exploited LGBT people on the pretext of Section 377. Being a Socialist Democratic Republic country, why does this have to be done in the 21st century?

So obviously, all these are self-contradictory, and, undoubtedly, Section 377 needs to be abolished. However, the legal battle for the existence of LGBT was going for about 20 years long. On 6th September 2018, the Supreme Court of India gave the verdict in favor of homosexuals by legalizing consensual intercourse between adults, irrespective of sex. But the path was not easy; there were many obstacles, which will be explained in this article.

Mainly my objective is to analyze why section 377 badly needed to be banned and how it deprived homosexuals by violating their freedom of choice with special criticism on political and jurisprudence overview.

\section{Basic concepts of gender and LGBT}

First, we have to understand the Gender and Sex concept along with the LGBTQ concept. In 1955 Sexologist John Money first explained the difference between biological sex and social sex, which was later referred to as gender. Sex refers to a set of biological attributes in humans and animals. Gender refers to the socially constructed roles, behaviors, expressions, and identities of girls, women, boys, men, and gender-diverse people. It influences how people perceive themselves 
and each other, how they act and interact, and the distribution of power and resources in society (Coen \& Banister, 2012). Although till the 1970 s no one gave importance to Money's theory. Now by the abbreviation of the term LGBTQ, we understood the gender identity and sexual orientation types in our society. So that the term LGBTTQIAAP includes all types of sexual orientation except heterosexual.

\section{METHODS}

This article focuses on the historic, legal, and political aspects of homosexuals in India with reference to Section 377. This article is established by case studies from various sources, and on the basis of these case studies, I conduct descriptive research in which it is clarified with examples and facts. Mainly, I use secondary data to conduct this study. Although the recourses are received from liberal sources as it has been mentioned later, there is a little case (legal and printed sources) available in the pre-independent era of India regarding homosexuality.

The article is being written during the COVID 19 situation and a nationwide lockdown period. So as much as printed resources (mainly books and printed journals) were needed, they were not available, but still, I try to limit this obstacle from online sources.

\section{The first law on homosexuality}

The date was 6th October 1860. Section 377 of the Indian Penal Code 1908 was introduced under the auspices of the Indian Law Commission and Thomas Babington Macaulay (First Law Member of the Governor-General's Council of British India) where it clearly stated that-

Whoever voluntarily has carnal intercourse against the order of nature with any man, woman or animal shall be punished with imprisonment for life or with imprisonment of either description for a term which may extend to ten years or with a death penalty and shall also be liable to a fine (Rao, 2017, p.127).

The main objective of this Section is that sexual intercourse is mandatory and anal or brutal sex is a punishable offense. In other words, the government wanted to control a citizen's private sex life. It indirectly indicates any unnatural sexual intercourse between a man and man or between a man and woman (anal sex) or between a woman and woman or between an animal and a man is considered a crime. If we analyze it deeply, then we can understand that it not only criminalizes homosexuality but also any intercourse that can't produce a child. Here we must understand the term 'Against the Order of Nature' which includes any sexual acts that can't give birth to a child because 'Order of Nature' means something which is biologically approved, and that is after intercourse a newborn will arrive, and thus a race is being carried out its lineage in the world. When intercourse doesn't produce a child, that means it neglects the Order of Nature. The concept of 'Carnal Intercourse' doesn't clearly emphasize in Section 377, but the intercourse which doesn't produce a child might be considered carnal or libertine. However, in the Suresh k. Koushal vs. Naz Foundation case, the court clearly distinguished between 'natural' and 'unnatural' sex by saying 'natural' is 'penile-vaginal' and 'unnatural' is 'penile-nonvaginal' penetrative sexual acts (2013, p.5). But obviously, being human, we all have emotions, desires, hopes, and it would not be rational to judge these in terms of 'Order of Nature' as these are subtle components of our mind. However, to understand this we took more than 150 years. 


\subsection{First court case regarding IPC 377}

The court case named Queen Empress v. Khairati in 1884 is the first reported case of the use of Section 377 against a person. The person who was arrested by the police on the grounds of habitually wearing women's clothes had committed the offense under Section 377. The medical examination of Khairati, as per the judicial record, showed that Khairati had "syphilis and exhibited signs of a habitual sodomite, had indeed committed the offense of sodomy" (Narrain, 2018, p.44). It is very surprising that in that ancient time a man had the audacity to wear a women's dress. Obviously, he had to face reprimand from the authority. Narrain remarked it as "gratuitous violence of arresting a person merely because their gender does not match their biological sex" (2018, p.45). Justice Straight called this sexual act 'disgusting practices'. This effectively put his or her (as her sex was not decided) outside the 'human pale', and one can only imagine the violation of the arrest. After this, she or he was subjected to an anal examination by the civil surgeon. The violation of bodily integrity and assault on her dignity emerged vividly (Narrain, 2018, p.45).

However, Justice Straight was unable to convict Khairati as "neither the individual, with whom the offense was committed nor the time of committal nor the place is ascertainable" (Narrain, 2018, p.45). But we can't ignore the violence to which he was subjected during the entire legal and police process. Khairati's case pointed to the fact that the person of 'other' gender is largely absent in the colonial legal record. The fragment that recorded Khairati's travails spoke to the question of a larger absence from the history of the lives and stories of those who were persecuted on the grounds of their gender identity.

\subsection{Nowshirwan vs emperor court case}

In 1935, a young Irani shopkeeper named Nowshirwan Irani was charged with having committed an offense under Section 377 with youth aged about 18 called Ratansi from Sind of British India. The case was portrayed as Nowshirwan had forced Ratansi to have carnal intercourse. Whatever the incident was, this happened in the house of Nowshirwan, and this was seen by Solomon, a police officer, and his friend Gulubuddin through the keyhole. Needless to say, they took Nowshirwan and Ratansi to the police station. However, in court the judge was not convinced by the prosecution's story. In the judge's opinion, “as the appellant did not even if we take the worst view against him go beyond a certain stage of lascivious companionship, I do not think he deserves to be convicted for any of the offences with which he was charged or could have been charged" (Narrain, 2018, p.46). There were reasons behind it. Firstly, the doctor who examined Ratansi was of the opinion that the lad must have been used frequently for unnatural carnal intercourse. Secondly, regarding that day's event, the judge's statement, while appreciating the medical evidence, was "There was not the slightest symptom of violence on the hind part of the lad" (Narrain, 2018, p.47). So, it was proved that Ratansi was coerced by those around him into posing as a complainant against Nowshirwan with whom he had earlier had a consensual sexual relationship. However, it was also assumed that the two knew each other and had possibly met before in Nowshirwan's room, and Solomon had noticed their previous meetings, hence he was on the alert to take action on that day in Sind in 1935. So, the Judge dismissed the case by saying "If he were in the house of the accused behind locked doors, I do not have the slightest hesitation in believing that he had gone there voluntarily" (Narrain, 2018, p.46).

Nowshirwan's story remains emblematic of the ethical and moral poverty of the judicial discourse for more than 160 years. Although there were no legal records regarding Section 377 other than these, but it doesn't mean that there was no existence of the LGBT community. They were there, but no one would talk about this because Indians were ashamed to talk about it, the protest was 
a far cry. So, we took 130 years to make a voice raised, which indirectly increased the misery of 'unnatural' people of India in those days.

\subsection{0 s Activities on homosexuality}

After the implementation of section 377, no voice or activities took place in more than hundred years, as I said earlier. But in the early nineties, first an organization named AIDS Bhedbhav Virodhi Andolan (ABVA), which means in English AIDS Anti-discrimination Movement, came forward for homosexuals. They published a report named Less Than Gay on the experience of homosexuals in India was published. Some statements of gay victims are as follows-

1. Someone named Rahul said, "In my tenth class, I fell hopelessly-in love with a boy one year my senior... Our affair continued for a year. He always felt guilty after sex and would go to his family mandir to pray.... We wrote love letters, had passionate telephone conversations much to the astonishment of our families. In recent years he got married. When he talked to me about it, what came through was his terror of social disgrace. Right now, he is being a good Rajput son with a wife and kids - goes to the mandir for Gita readings - in short, living the classic life of the closet gay" (ABVA, 1991, p.8).

2. Ishwar Kale, a 32-year-old industrial worker from Bombay said, "They think we are enemies of prakruti (nature) and of sanskruti (culture) ... people refuse to believe that IT can work between man and man" (ABVA, 1991, p.9).

3. Someone from Mizoram, reluctant to disclose his or her name, said, "After a lot of thinking, I have come to a conclusion. I have been alone and single in the love, sex, etc., department for 20 years. I can see that I am living a bloody big lie, but I can't really come out because of various factors. So I am going to ignore my love, sex areas, and I will put all my energies into my work. If I could have lived for 20 years without a lover or boyfriend, I know I can live for another 20" (ABVA, 1991, p.9).

4. A married gay guy said, "As I see things now, most gay men in India get married off and fool themselves (besides their wives) then try to give the impression of living happily ever after. Then they advise other bachelor friends to marry. No small wonder, more than half the gays who cruise in my area are married" (ABVA, 1991, p.10).

Like these, there are so many examples. ABVA first raised a voice against those things. Their observation was,

ABVA views homosexuality (and heterosexuality) as a political issue. We will strive to get consensual, adult homosexual acts decriminalized and fight for the right of gay men, lesbians and other 'sexual minorities', like hijras, to enjoy equal benefits of the laws on marriage, inheritance, adoption, and privacy, among others. We feel that a clear and unambiguous stand should be taken by political parties and civil rights organizations on the human rights of gay men and lesbians. This alone can root out police harassment, blackmail, violence, and other forms of discrimination from their daily lives. Gay and non-gay people alike also urgently need relevant, non-moralistic safer sex education in the context of AIDS. (1991, p.4-5)

They didn't just throw a comment, but they set out various examples like Barry John, some Prem from Calcutta, auto-rickshaw driver Indu of Poona, Arijit of New Delhi, Chandrakant of Shahdara, Arun-Kamal, a lover duo near Dabar Station in Bombay and millions of like them, in their report so that they can prove there are considerable number of homosexuals who are needed equal rights and ABVA was working for them. 
The controversy erupted in May 1994 when Kiran Bedi, the inspector general of Delhi's Tihar Jail, refused to provide condoms for inmates (Thomas, 2018). She said it would encourage homosexuality and indirectly admitted that prisoners were involved in homosexual intercourses. In response, ABVA files a writ petition in the Delhi high court, demanding that free condoms be provided, and that Section 377 be recognized as unconstitutional. They mentioned in their petition that Section 377 is violative of the fundamental rights of Indian citizens, and in this regard, they put forward the following reasons.

1) Section 377 is violative of Art. 14 of the Constitution since it discriminates against people purely on the basis of their sexual orientation.

2) The right to privacy is part \& parcel of the fundamental right to life \& liberty under Art. 21, of the Constitution and has also been recognized by the International Convention on Human Rights 1948.

3) Section 377 is archaic \& absurd, passed by the British in all its colonies. Campaigns in other countries have resulted in decriminalizing private adult homosexual consensual acts (in England \& Wales in 1967, Hong Kong in 1990). India is one of a few countries to retain this law.

4) Homosexuality is 'imported' from the West is an erroneous supposition as Indian art, sculpture \& sexual manual 'Kamasutra' will testify.

In addition to these, ABVA also put forth Amnesty International's report on homosexuality (1987), Kinsey report on Human Sexuality (1948-53) where it was said $2 \%$ of women are lesbian \& $4 \%$ of men are gay, and American Psychiatric Association declaration - homosexuality is perfectly normal-in favor of their petition. But unfortunately, after a long struggle, the petition was eventually dismissed in 2001.

\subsection{NAZ Foundation \& legal actions}

A gay sexual health organization named Naz Foundation filed public interest litigation (PIL) in Delhi High Court by challenging Article 377 and legalizing homosexuality in December 2001. And the case was dismissed in 2004 by a two-judge Bench of Chief Justice B. C. Patel and Justice Badar Durrez Ahmed of the Delhi High Court by saying there is no cause of action and that purely academic issues cannot be examined by the court. A review petition filed by the Naz Foundation is also dismissed a few months later.

Naz Foundation again filed a special leave petition (SLP) for the case in February 2006 and the Supreme Court reinstated it in Delhi High Court, citing it as a matter of public interest. In 2006, Voices against 377 , a coalition of gender and child rights groups, became an intervening party to the petition.

It must be noted that till now the government and other political parties were silent on this matter. For the first time the Ministry of Home Affairs under Shivraj Patil and Dr. Anbumani Ramadoss of the National AIDS Control Organization (NACO) under the Minister for Health and Family Welfare filed separate and contrarian affidavits - the former against the decriminalization of section 377; the latter arguing that criminalization impeded the efforts to control HIV or AIDS.

On 2nd July 2009, a historic verdict for homosexuals came out in the judgment of the Delhi High Court. Chief Justice Ajit Prakash Shah and Justice S. Muralidhar division Bench said that Section 377 does not apply to consensual sex of LGBTQ people over 18 years of age. The two judges argued that it was a violation of the fundamental rights of the Indian Constitution to criminalize 
adult homosexuality if it was consensual. They said,

We declare that Section 377 IPC, as far as it criminalizes consensual sexual acts of adults in private, is violative of Articles 21, 14 and 15 of the Constitution... The provisions of Section 377 IPC will continue to govern non-consensual penile non-vaginal sex and penile non-vaginal sex involving minors (Nair, 2018).

A huge controversy was raised in Indian society. A Delhi-based astrologer named Suresh Kumar Kaushal challenged the verdict and appealed to the Supreme Court.

\subsection{Story of professor Siras \& Aligarh Muslim University}

Professor Siras's story might not be relevant with this article, but the story helps us to understand, despite court judgment every day, how millions of gay Indians are tortured, humiliated, and suppressed by conventional society. And this will help us to understand that if the scenario of India is still the same even after the read down of Section 377; so, what was the misery of homosexuals when Section 377 was there because of the incident of Siras was happened in 2010 when the Delhi high court gave that verdict and the new verdict on 377 hadn't come yet. So technically, consensual same-sex intercourse was legal, but Professor Ramachandra Siras was alleged to have sex with some rickshaw driver in his personal room, and for this misconduct, the Aligarh Muslim University (AMU) authority suspended him. The incident happened at midnight on the midnight of 8th February 2010 in his university quarter room where some of his colleagues and a local TV channel's camera crew entered his room forcefully and captured Siras and his partner's intimate video without their consent. In the very next day by organizing a press meet AMU described the whole incident and AMU public relations officer Rahat Abrar stated, "Siras was captured on camera having sex with a rickshaw-puller. He was placed under suspension by the order of the vice-chancellor, Professor P. K. Abdul Aziz" (Pant, 2010, p.7).

The torture towards Siras was not finished yet. He was thrown out from the university quarter, and he didn't get any rental house in the city. No one wanted to give home to a gay. As we discussed earlier, at that time consensual sex between two adults irrespective of gender was legalized by Delhi HC; so, he filed a petition based on 2009's verdict against the university in Allahabad High Court. Here a question may arise that being a central government university, how AMU was unaware of the law, or they intentionally ignore it as if they are making their own law and don't care about the court? However, he won the case in the Allahabad High Court on 1st April 2010 and got his job as a professor, along with his accommodation, until his retirement. Even the court reprimanded those who were involved in the covert taping and ambush of Siras and his partner because by intervening in someone's private matter they committed a crime. This proved how important the verdict of 2009 is for homosexuals' existence. Although, after a couple of years Article 377 will be again enacted by the Supreme Court, which will be discussed afterwards.

However, Siras was not guilty. But on 7th April 2010, the day before his university rejoining, Siras was found dead in his apartment. At first, police suspected suicide, but preliminary reports from the autopsy showed traces of poison in his body. On 19 April, the Superintendent of Police stated that three journalists and four AMU officials were named as part of the crime. The case was closed without resolution after the police failed to find sufficient evidence. Though it can easily be assumed whether it is murder or suicide, but as per the verdict, this was suicide. These incident questions, despite the court's verdict, if a gay was tortured and exploited like this, then what was the situation during article 377. 
I spent two decades here. I love my University. I have always loved it and will continue to do so no matter what. But I wonder if they have stopped loving me because I am gay - Ramachandra Siras (Quoted by Ganjapure, 2010).

\subsection{Suresh Kumar Koushal Vs Naz Foundation Court Case}

As we discussed earlier, a Delhi-based astrologer, Mr. Koushal and other filed an appeal to the Supreme Court to review the Delhi HC's judgment and regarding this case, the two judges, Bench of Justices G. S. Singhvi and Sudhansu Jyoti Mukhopadhaya, of SC overturned the Delhi HC's judgment. That means homosexuality is again a punishable offense. A huge controversy was arisen nationwide. Many news media broadcast discussions and critical analysis along with gay activists and lawyers. The verdict of SC highlighted the minor people were insignificant. The SC criticized the HC by saying "While reading down Section 377, the High Court overlooked that a miniscule fraction of the country's population constitutes lesbians, gays, bisexuals or transgender, and in more than 150 years past, less than 200 people have been prosecuted for committing an offence under Section 377" (Venkatesan, 2013). The judge duo seemed to have freed the country from the evil stigma of minor homosexuals. The court left it to Parliament to "consider the desirability and propriety of deleting Section 377 IPC from the statute book or amend the same" if it so wished (Nair, 2018). That means then it was the responsibility of the government to amend or delete the existing IPC 377. It depends on the government who is in power. A review petition filed by Naz Foundation, the union government, and others in 2014 were quashed by the SC.

\subsection{Post-Verdict Protests}

After the one-year completion of the SC verdict, many gay-lesbian and transgender people gathered in Delhi to protest the verdict. Some eminent gay and transgender activists like filmmaker Sridhar Rangayan, social activist Laxmi Narayan Tripathi and the chairman of National Human Rights Commission as well as former chief justice K. G. Balakrishnan took part in the program. Balakrishnan said, "Human rights of the LGBT Community need protection, and they should not be classified as criminals" (Rao, 2017, p.130).

Here we must mention the 21st Conference by Visible Evidence which was held in New Delhi on December 11-14, 2014 where a workshop took place on the theme "LGBTQ Documentary in India After 377: Where are We Coming from; Where are We Going?" At the 3rd day of the conference at 3:30-5:00 pm. A documentary film named No Easy Walk to Freedom by Nancy Nicol was shown in this workshop where Justice A. P. Shah, who gave the judgment to read down 377 in 2009, appeared and minutely distinguished between 'constitutional morality' and 'colonial legislation'. It was shown in the film that after the 2009 judgment on how gay and transgender were coming out and their families were accepting them (Rao, 2017, p.133). But when SC dismissed the verdict of Delhi HC, these homosexual people became again unacceptable to the society.

A survey by an NGO called SPACE (Society for People's Awareness, Care and Empowerment) revealed shocking information regarding homosexual deprivation. Within three months of the Supreme Court judgment, one gay and three transgenders were brutally murdered. In many cases, homosexuals were being persecuted. It was also not possible to complain to the police because in that case the police would arrest those homosexuals because homosexuals are criminal as per 377. Many homosexuals were being evicted. We can recall the drastic incident that happened to transgender Rudrani Chettri in Simla where she was brutally beaten by a police constable (Rao, 2017, p.131). We all know homophobic sneers and mockery attract in society. A boy was mocked for his sexuality, and thus he was unable to take his exam. In this context of harassment, the boy approached the court for a chance to do his exam again (Narrain and Eldridge, 2009, p.49). 
During Suresh K. Koushal vs Naz Foundation case, senior counsel Mr. Shyam Divan read out the one from Kokila, a transgender person who was brutally raped by the police (Narrain, 2018, p.5657). Senior counsel, Mr. Ashok Desai, read out the second affidavit from Vijaylaxmi Rai Chaudhari, the mother of a gay man:

My child is living with the agony and disrespect of being penalized at any point of time under an unjust law. It stopped him from coming out for long. Even after he came out, he always felt insulted since he can't live his life equally celebrated and accepted by the law and the society. The thought that Anis could for no fault of his own be harassed by the state makes Section 377 unacceptable for any otherwise law-abiding, just, and self-respecting citizen (Narrain, 2018, p.57).

Many gays claimed that condoms were not as readily available as before. That means the court curtailed their right to have safe sex. Even the government hospital was refusing to give AIDS-infected homosexuals Antiviral Therapy (ART) (Rao, 2017, p.131).

Nevertheless, the struggle continued. Eminent personalities of Lawyers' Collective like Anjali Gopalan, Anand Grover and Gautam Bhan filed a petition in the court seeking reconsideration of the case. Many gay people came forward. Some of them are Ashok Kavi of Humsafar Trust, Manohar of Sangam and Arvind Narrain, co-editor of the book Because I Have a Voice (another one is Gautam Bhan).

In this prime-time Indian superstar Aamir Khan discussed this topic in his television program Satyamev Jayate which was broadcast on 19th October 2014 on Star Plus channel. It is a very venturesome step for Aamir Khan because being a mainstream entertainer, this broadcast might hamper his stardom and diminish his fan base. In addition to these, at that time LGBT people and homosexuality was illegal, so by doing a conversation on this show authority committed a crime. Fortunately, none of these happened. Instead, many progressive minds appreciated this. In this program, a gay activist and psychologist, Deepak Kashyap, and a lesbian screenwriter, Gazal Dhaliwal, expressed their experience being a homosexual. Psychologist Anjali Chabbra psychologically discussed the mental status of homosexuals. Even after this program, Aamir Khan did a follow-up named Mumkin Hain where he welcomed the audience to tweet at 377. Almost 16000 people tweeted to abolish section 377 .

\subsection{Political Activities Regarding Homosexuality}

Contradicting to section 377, the Congress leaders, Sonia Gandhi and Rahul Gandhisaid that this law was against the personal will of the people. Delhi Chief Minister Arvind Kejriwal's Aam Aadmi Party (AAP) has also pledged to help protect the fundamental rights of homosexuals. Even many members of AAP were lawyers by profession, so they said that to get rid of the 1960s law an amendment was necessary. Members like Yogendra Yadav, Prashant Bhushan said that they would give equal precedence to minors. But the indifference of the Bharatiya Janata Party (BJP) made it clear that they would not make any constitutional amendment to repeal Article 377. As a Hindu fanatic party, they believed that homosexuality is against Indian culture. According to the BJP, homosexuality is a Western concept. This is limited in the Indian upper-class society and is useless to the major proportion of middle-class Indians. For most Indians, life is restricted in marriage, children, and family. It seems homosexuals are minor and non-existent to the government. Member of Rajya Sabha Rakesh Sinha once said that it was not Indians' demand to abolish section 377, but it was foreigners' intention to abolish section 377 so that they can tempt Indians towards perversion and filth (Rao, 2017, p.151). But in November 2015 the then Finance Minister Arun Jaitley spoke of repealing section 377 because it has "adversely affected millions of Indian citizens and their right to live a life of dignity and equality" (Rao, 2017, p.147). It was very astonish- 
ing that Mr. Jaitley gave a statement two years earlier where he said the Court couldn't decide the constitutional validity of 377 , which contradicted his subsequent statement. However, if they do that, they have to face the wrath of Rashtriya Swayamsevak Sangh (RSS), Shiv Sena, Maharashtra Navniraman Sena (MNS), Vishwa Hindu Parishad, Hindu Mahasabha and Bajrang Dal. So, no doubt that they don't want to offend their allies as BJP came to power with their help. Even in the BJP there was dissent. It was clear when in a debate program of NewsX channel, a BJP leader and MP Subramanian Swamy directly challenged his party's member Jaitley. He said homosexuality enhanced atrocity of the human. In one side there were people like Jaitley, RSS Deputy General Secretary Dattatreya Hosabale, who said that homosexuality is not a criminal act and it is wrong to declare it illegal, although he added it is aberrant and added "no criminalisation, but no glorification either" (Tiwari, 2016) and in other side there were Yogi Adityanath (CM of Uttar Pradesh), Baba Ramdev and Swamy who claimed homosexuality is a curable disease and should not be legalized. Even Hosabale was also criticized for his statement by BJP's spokesperson Saina NC who advised Hosabale to be more careful when she talked. So, it was clear that in the BJP there was dissension regarding 377 abolitions.

In December 2015 and in March 2016, Congress leader, MP from Thiruvananthapuram and writer Shashi Tharoor introduced a private members bill in the parliament against section 377. But two bills were rejected in Parliament. It was rejected for the first time because twenty-four members were in favor of the bill and seventy members were against the bill. Second time eighteen members gave vote to this bill and 58 were against it. He was asked when his party was in power why they didn't amend the bill. In return, he argued that in December 2013 when the verdict of SC came out, they didn't get much time to introduce this bill as in May 2014 a new BJP government came into power. In his bill he showed how LGBT people got tortured after 2013's verdict. He showed after the 2013 judgment 578 gays were arrested. He said, "As far as I am concerned, this is not just one particular [sexual] practise, as the enemy is portraying. Instead, it is about freedom guaranteed by the constitution of India" (Rao, 2017, p.148). Tharoor understood 377 couldn't be eradicated in the parliamentary way.

\subsection{Contemporary Legal Activities Related To Section 377}

\section{National Legal Services Authority VS Union of India Court Case}

On 15 April 2014, the Supreme Court gave a landmark decision which declared transgender people the 'third gender', affirmed that the fundamental rights granted under the Constitution of India will be equally applicable to them, and gave them the right to self-identification of their gender as male, female or third gender. The two-judge bench composed of Justice K.S. Radhakrishnan, and Justice Arjan Kumar Sikri gave the verdict. Some said this judgment has been distinguished as a major step towards gender equality in India because transgender people were treated socially and economically backward classes, they will be granted reservations in admissions to educational institutions and jobs. But if we deeply analyze it then, we can understand that this verdict is contradictory with December 2013's verdict. Let's understand why. Suppose a transgender male partially feels like a female. Now as per 2014's verdict, transgender and gay people enjoy equal rights like others as it provides special reservation for the third gender in education and jobs. That means the Court exempted the third gender from section 377. Now if a gay man has homosexual intercourse with a transgender man, then that gay man will be found guilty. This is as if the Supreme Court accepts the rights of the third gender but criminalizes them on their sexual orientation. This is how contradictory the two verdicts were. So, Raju Ramachandran, who is the advocate of the petitioners of third gender rights, said, "One court, two mindsets" (Rao, 2017, p.136). 
The second most confusing thing is how the court identifies a third gender person? Castration is not the ultimate solution. Many homosexual men are feminine in nature, so to get legal benefits they can claim to be transgender. Some consider cross-dressers and feminine males transgender. Transgender is a physiological condition which is difficult to describe in a medical term. Homosexual and heterosexual men are physiologically indifferent and to get legal benefits they claim to be transgender by deception.

As Justice Radhakrishnan and Sikri couldn't disobey the previous judgment of the court, they clearly stated that the term 'Transgender' would not be described in a wider meaning that includes Lesbian, Gay and Bisexual words. That means if a transgender person is homosexual, then his or her or her rights are acceptable, but when he or she or she is gay, then his or her rights are deniable - it really sounds ridicules.

However, it is not possible to give reservation to transgender people in government service without the consent of the National Commission for Backward Classes (NCBC). But in India, Hijars are the face of LGBT people who are seen to do begging, dancing, singing, and prostituting. If the government took the necessary measures, then it can happen. Instead, the then government challenged the verdict of 2014 . So, it is clear the government was not willing to give a single recognition to LGBT people.

\section{Delhi Session Court Case on Sex-toys Indirectly Related to Homosexuality}

A Delhi-based lawyer Suhaas Joshi has filed a lawsuit in Delhi Sessions Court, specifically Tis Hazari court, saying that sex-toy should be banned in India if it is a Section 377 offense as it is also an 'unnatural' sexual act. His complain was against two online sales websites named Snapdeal. com and Chennai-based Ohmysecret.com who were selling sex toys online like Vibrator, Massager, Deldo, lasting lubricants etc. which enhances the tendency of gay sex that is illegal according to Section 377. Instead of dismissing this absurd petition, the court ordered to investigate the police where and how it was sold. Metropolitan Magistrate Richa Gusain Solanki directed the Station House Officer (SHO) of Sabzi Mandi police station of New Delhi to conduct the preliminary probe. It was clear that anything relating to the violation of article 377 was strictly suppressed by the government. Now the question arose: how does the sale of sex toys inevitably lead to unnatural sexual activity? The question is, if they excite sexual desire, how it can be possible to ban the sale of fruits that stimulate sexual desire because it is also an unnatural sex. But the court's logic was that under Section 377, voluntary "carnal intercourse against the order of nature with any man, woman or animal" is punishable with imprisonment from 10 years to life (Anand, 2015). Anyhow, when the question arose about the relevance of this PIL, no relevant positive reply came. If we logically think that anything can initiate sexual desire. So as per section 377 both are carnal activity and a punishable offence, but is it not under someone's personal choice? Simultaneously, how do government bands sex toys? There was no answer. If they did so, then there are many alternative ways to have unnatural sex. So, there was no basis for this PIL, and after a couple of months this PIL was dismissed.

\section{Naz Foundation Curative petition}

The final hearing of the petition submitted by the Naz Foundation is scheduled on February 2, 2016 in SC. A three-judge bench headed by Chief Justice of India T. S. Thakur said that all the 8 curative petitions submitted would be reviewed afresh by a five-member constitutional bench. It was very important because the result of the case depends on the mindset of the judges, and the judges who gave judgment in 2009 would also be present in the hearing as a part of the larger 
bench. However, the Supreme Court couldn't form five judge bench till then. It was very suspicious that the judges of SC couldn't agree on the constitutional validity of Section 377.

Justice K. S. Puttaswamy (Retd.) Vs. Union of India Court Case

On 24 August 2017, the Supreme Court finally gave a verdict in the favor of LGBT people. The Court held that the right to privacy is a fundamental right protected under Article 21 of Part III of the Indian Constitution. In the judgment headed by Justice K. S. Puttaswamy said, "A Discordant note which directly bears upon the evolution of the constitutional jurisprudence on the right to privacy" (Gharg, 2017, p.5). Chandrachud, one of the judges of the nine-judge bench, said the reason behind the 2013 verdict was wrong. Judge Sanjay Kaul agreed with Chandrachud that the right to privacy of minorities could not be denied, and in the case of constitutional rights, the concept of the majority was unacceptable. The opinion of minorities in India must be considered in maintaining the balance of power under the Indian constitution. In addition, they said that sexual orientation is an important part of privacy and discriminative treatment towards a person based on sexual orientation is highly offensive to a person's self-worth and dignity. Articles 14, 15 and 21 of the the Constitution include the right to privacy and protection of sexual orientation under fundamental rights.

\section{Navtej Singh Johar Vs Union of India Court Case}

\section{Background}

In 27 June 2016, Bharatnatyam dancer and Sangeet Natak Akademi awardee Navtej Singh Johar, journalist Sunil Mehra, chef Ritu Dalmia, hoteliers Aman Nath and Keshav Suri, and businesswoman Ayesha Kapur filed a writ petition in the Supreme Court challenging IPC 377 (The Naz Foundation case was a PIL). The Naz had been earlier referred to a five-judge bench to decide whether the curative petition could be accepted for consideration which had been discussed earlier. The NDA government took a neutral stance, leaving the decision to the "wisdom of the court" as long as it applies to "consensual acts of adults in private" (Chaturvedi, 2018).

Trial

The petition was first placed before Justice S. A. Bobde and Justice A. K. Bhushan on 29 June 2016. An order was passed to post the matter before the Chief Justice of India Dipak Misra for appropriate orders since a curative petition was already pending before the constitution bench. On 8 January 2018, the case was listed to be heard by the Chief Justice's bench, which passed an order stating that the case would be heard by a constitution bench. The matter was heard from 17 January 2018 by a five-judge bench consisting of CJI Dipak Misra and Justice R. F. Nariman, D. Y. Chandrachud, A. M. Khanwilkar and Indu Malhotra of the Supreme Court. The petitioners cited sexual privacy, the right to expression against discrimination as fundamental rights against Article 377. The bench ended its hearing on 17 July and reserved its verdict, asking for both sides to submit written submissions for their claims by 20 July. Finally, September 6, 2018, was selected by SC to give the verdict.

\section{Judgment}

September 7, 2018, was a long-awaited day. Recognizing the constitutionality of the third gender, the court declared that Article 377 was "irrational, arbitrary and incomprehensible" (Hans, 2017). The supreme Court clearly stated consensual sex between adults in private space, which is not harmful to women or children, cannot be denied as it is a matter of individual choice. Section 377 results in discrimination and is violative of constitutional principles. This decision overturned the 
2013 ruling in Suresh Kumar Koushal vs. Naz Foundation in which the court upheld the law. The court put forward the opinion behind this verdict. It was "Sexual orientation is natural. Discrimination on the basis of sexual orientation is a violation of freedom of speech and expression" (Bharadwaj, 2018, p.11). However, other portions of Section 377 relating to sex with minors, non-consensual intercourse, and bestiality, i.e., sexual acts with animals, remain in force. In addition, the five-judge bench made a concluding statement regarding their verdict which is as follows:

An examination of Section 377 IPC on the anvil of Article 19 (1) (a) reveals that it amounts to an unreasonable restriction, for public decency and morality cannot be amplified beyond a rational or logical limit and cannot be accepted as reasonable grounds for curbing the fundamental rights of freedom of expression and choice of the LGBT community. Consensual carnal intercourse among adults, be it homosexual or heterosexual, in private space, does not in any way harm the public decency or morality. Therefore, Section 377 IPC in its present form violates Article 19 (1) (a) of the Constitution (Narrain, 2018, p. 32).

\section{CONCLUSIONS}

At last, homosexuals got freedom and freed from the dark age of Section 377. From 6th September 2018, consensual sex between two adults irrespective of sex was not a crime. As I have mentioned, the historical background and through which we can understand why this judgment is so valuable and important for LGBT people. Finally, it was the end of so many humiliations, oppression and disregard and the beginning of a new dawn where people, regardless of race, religion, caste, sex, culture as well as sexual orientation, are of one identity that is human. They have the equal opportunity and equal right in every aspect which Ashok Kavi described as "We are finally azaad in azaad Hind (Independent in independent India)" (Jha, 2018). However, consensual sexual intercourse between an adult individual is legalized, but other rights are still elusive. For example, same-sex marriage is not legally constitutional; only consensual intercourse between adults is permitted. In this case, recently, members of the LGBTQ community filed a petition in Delhi High Court seeking legalization of same-sex marriage under the Hindu Marriage Act. They have argued that Article 5 of the Hindu Marriage Act, 1956 stated that two Hindus might get married, and therefore there could be no objection to same-sex marriage between two Hindus of the LGTBQ community. Although the government has denied this and said same-sex marriage opposed several criminal and civil laws. So, there is still a huge fight waiting for homosexuality. On the other hand, there is a need to change social concept along with the law and the political parties reluctant to do anything for the liberty of homosexuals. If the society doesn't accept homosexuals, then no law can recognize them. Many NGOs and social organizations are working on this and making aware people of the LGBT. But I hope that people's attitude towards LGBT people are changing. Today in the LGBTQ pride march not only homosexual people but also heterosexuals walk in support of the LGBT community.

\section{REFERENCES}

Aids Bhedbhav Virodhi Andolan (ABVA). (1991). Less Than Gay: A Citizens Report on the Status of Homosexuality in India. Prince Offset Printers.

Anand, U. (2015, February 23). Does sale of sex toys violate Section 377, asks Delhi court. The Indian Express. https://cutt.ly/Dmb54BD

Bharadwaj, A. (2018, September 6). 'Gay sex is not a crime,' says Supreme Court in historic judgment. The Times of India. https://cutt.ly/7mb6RLh

Chaturvadi, A. (2018, July12). Government Leaves Fate of Section 377 to Wisdom of Supreme Court. Bloomberg. https://cutt.ly/Mmb6oT8 
Coen, S. \& Banister, E. (Eds.). (2012). What a difference sex and gender make: a gender, sex and health research casebook. Canadian Institutes of Health Research. https://cihr-irsc.gc.ca/e/48642.html

Ganjapure, V. (2010, April 9). Gay prof was known as a literary genius. The Times of India. https://cutt.ly/ Fmb6hVa

Garg, A. \& Mahapatra D. (2020, September 15). Can’t legalise same-sex marriage: Government. The Times of India. https://cutt.ly/mmb6zjy

Gharg, A. (2017). The Right to Privacy and What it means to India. Journal on Complementary Issues of Law. 3(10). 1-10. https://cutt.ly/7mb6cEt

Hans, N. (2017, February 14). Increasing support for gay rights from BJP leaders: A rainbow in sight?. Catch News. https://cutt.ly/2mb6Im5

Jha, L. (2018, September 6). Section 377: Top 10 quotes from SC verdict that decriminalises homosexuality. The Statesman. https://cutt.ly/smb6Jod

Khan, A., \& Bhatkal, S. (dir.). (2014). Accepting Alternative Sexualities [Television Talk Show Episode]. In A. Khan, \& K. Rao. Satyamev Jayate. Star India Network.

Laxmikainth, M. (2020). Indian Polity. McGraw Hill Education

Nair, S. (2018, January 11). Many ups and downs in battle against 377. The Indian Express. https://cutt.ly/ umb6SMI

Narrain, A. \& Eldridge M. (Eds.). (2009). The Right That Dares to Speak Its Name. Alternative Law Forum.

Narrain, A. (Ed.). (2018). Right to Love. Alternative Law Forum.

Nicol, N. (dir.). (2014). No Easy Walk to Freedom [Documentary Film]. India and Canada: Naz Foundation (India) Trust, Naz Foundation International and Envisioning Global LGBT Human Rights.

Nicol, N., Jjuuko, A., Lusimbo, R., Mulé, N. J., Ursel, S., Wahab, A. \& Waugh, P. (Eds.). (2018). Envisioning Global LGBT Human Rights: (Neo)colonialism, Neoliberalism, Resistance and Hope. University of London.

Pant, S. (2010, 1 July). Professors hounded out for being Gay. Mail Today. https://cutt.ly/gmb6Glm

Rao, R.R. (2017). Criminal Love?-Queer Theory, Culture, and Politics in India. Sage.

Thomos, M. (2018, September 6). Timeline: The straggle against section 377 began over two decades ago. Quartz India. https://cutt.ly/smb6XiW

Tiwari, R. (2016, March 19). Section 377: Unlike RSS, BJP shies away from taking a standon homosexuality. The Economic Times. https://cutt.ly/Wmb6CQD

Vanita, R., \& Kidwai S. (Eds.). (2001). Same Sex Love in India: Readings from Literature and History. PALGRAVE.

Venkatesan, J. (2013, December 11). Supreme Court sets aside Delhi HC verdict decriminalising gay sex. The Hindu. https://cutt.ly/Jmb6B4N

\section{AUTHOR}

Abir Mondal. B.Sc (Honours) \& M.Sc in Zoology. B.Ed Trainee at present

\section{Conflict of interest}

No potential conflict of interest is reported by the author.

Funding

No financial assistance from parties outside this article.

\section{Acknowledgments}

The author would like to thank Sourav Das, Assistant Professor, Siliguri B.Ed College, for his support. 